\title{
Prevalence of work-related respiratory symptoms in Iranian farmers
}

\author{
$\mathrm{N}$ Hashemi $M D^{1}, M$ Mirsadraee $M D^{2}, M T$ Shakeri $\mathrm{PhD}^{3}, \mathrm{AR}$ Varasteh $\mathrm{PhD}^{4}$
}

N Hashemi, M Mirsadraee, MT Shakeri, AR Varasteh. Prevalence of work-related respiratory symptoms in Iranian farmers. Can Respir J 2006;13(4):198-202.

BACKGROUND: Animal exposure may be an important trigger for work-related symptoms among farmers.

OBJECTIVE: To estimate the prevalence of work-related respiratory symptoms (WRS) in sheep breeders and agricultural farmers and to determine work-related risk factors.

METHODS: A family doctor used a questionnaire to interview a cohort of 173 farmers comprised of 127 sheep breeders and 46 agricultural farmers in the rural area of Rokh (northeast Iran). The questionnaire pertained to recurrent wheezing, cough, breathlessness or chronic phlegm while at work (these symptoms define WRS), flu-like illness and physician-diagnosed asthma.

RESULTS: There were 71 subjects (41\%) with WRS: 10 of 46 agricultural farmers $(21.7 \%)$ and 61 of 127 sheep breeders $(48.0 \%)$. The proportions of sheep breeders with wheezing $(16.5 \%)$, asthma (14\%), cough (29\%), breathlessness (31.5\%) and flu-like illness (38\%) were higher than in agricultural farmers. A significant dose-response relationship among the daily hours worked with animals, the number of animals and the prevalence of symptoms was established for sheep farmers. Sheep shearing and the use of pesticide were associated with an increased risk of wheezing and phlegm.

CONCLUSIONS: The results suggest that sheep farmers in general have higher rates of work-related symptoms than agricultural farmers. The severity of work-related symptoms will increase with an increase in frequency of animal contact; therefore, these results may underestimate the impact of this exposure.

\section{La prévalence des symptômes respiratoires professionnels chez des fermiers iraniens}

Key Words: Asthma; Flu-like illness; Pesticide; Sheep breeders; Work-related respiratory symptoms

Farming has been known as a high-risk occupation for the Fdevelopment of work-related symptoms since 1555 , when Olaus Magnus recognized farming health hazards with respect to grain dust (1). Farmers involved in animal production have a higher prevalence of respiratory symptoms than other farmers and other rural residents. An increase in respiratory symptoms has been noted among animal farmers in North America, Europe and New Zealand (2,3). Although the prevalence of smoking is lower in farming than in other occupations (4), farmers have a greater risk of respiratory disorders than people in nonfarming occupations (5). While at work, animal farmers are exposed to inorganic dust, and organic
HISTORIQUE : L'exposition aux animaux peut être un important déclencheur de symptômes professionnels chez les fermiers.

OBJECTIF : Estimer la prévalence des symptômes respiratoires professionnels (SRP) chez des éleveurs de moutons et des agriculteurs et déterminer les facteurs de risque professionnels.

MÉTHODOLOGIE : Un médecin de famille a utilisé un questionnaire pour interroger une cohorte de 173 fermiers composés de 127 éleveurs de moutons et de 46 agriculteurs dans la région rurale de Rokh (au nord-est de l'Iran). Le questionnaire portait sur la récurrence de wheezing, de toux, d'essoufflement ou de mucosités chroniques au travail (ces symptômes définissent les SRP), sur les maladies pseudogrippales et sur l'asthme diagnostiqué par le médecin.

RÉSULTATS : Soixante et onze sujets (41\%) souffraient de SRP : 10 des 46 agriculteurs $(21,7 \%)$ et 61 des 127 éleveurs de moutons (48,0 \%). La proportion d'éleveurs de moutons souffrant de wheezing (16,5\%), d'asthme (14\%), de toux (29\%), d'essoufflement $(31,5 \%)$ et de maladies pseudogrippales (38\%) était plus élevée que celle d'agriculteurs. Chez les éleveurs de moutons, on constatait une importante relation entre la dose et la réponse pendant les heures quotidiennes travaillées auprès des animaux, ainsi que selon le nombre d'animaux et la prévalence des symptômes. Le rasage des moutons et l'utilisation de pesticides s'associaient à une augmentation du risque de wheezing et de mucosités.

CONCLUSIONS : D'après les résultats, en général, les éleveurs de moutons présentent des taux plus élevés de symptômes professionnels que les agriculteurs. La gravité des symptômes professionnels est proportionnelle à la fréquence des contacts avec les animaux. Par conséquent, les présents résultats sous-estiment peut-être les répercussions de cette exposition.

\footnotetext{
${ }^{1}$ International Institute of Health Studies, Ottawa, Ontario; ${ }^{2}$ Department of Pulmonary Medicine, Islamic Azad University of Mashhad;

${ }^{3}$ Department of Medical Statistics; ${ }^{4}$ Immunology Research Center, Mashhad University of Medical Sciences, Mashhad, Iran

Correspondence: Dr Nastaran Hashemi, 12531 26th Avenue Northeast, Seattle, Washington 98125-4301, USA. Telephone 206-364-1601,

fax905-763-9771,e-mail hashemi_nastaran@yahoo.com or hashemi@iihs.ca
} 
bacteria (Pseudomonas species) and bacterial endotoxin found in sheep fleece (10). Americans first described the flu-like illness as a febrile reaction to organic dust exposure (11). Farmers with bronchial hyper-reactivity attributed the onset of their airway disease to the flu-like episode occurring after an abnormally severe dust exposure incident (12).

Farming is commonly a lifelong occupation (13). Because farmers often live at their farms, they can continuously be exposed to hazardous agents, and due to animal and plant cycles, exposure patterns at farms may vary over the course of a year. Climatic differences among agricultural areas lead to a variety of farmer exposure patterns across different countries (14).

The present study focuses on the prevalence of work-related symptoms in sheep breeders compared with that of agricultural farmers. The aim of the study was to determine which occupational symptoms are predominant among farmers and to explore potential risk factors for sheep breeders.

\section{METHODS}

\section{Study area and population}

The study area included the mountainous rural areas of Rokh and Kadkan, located in northeast Iran. The area has a population of 30,000 , many of whom are farmers.

\section{Protocol}

We used a Farsi questionnaire (see Appendix) derived from the European Community Respiratory Health Survey questionnaire and the European animal farmers' survey $(11,13,14)$. The first part of questionnaire included questions on work-related respiratory symptoms (WRS), nasal irritation, eye irritation and flu-like illness within the preceding year $(11,14)$. WRS was defined as wheezing, breathlessness, cough or phlegm while at work. A sudden onset of fever, chills, muscle ache, weakness, headache, cough, chest tightness or breathlessness $2 \mathrm{~h}$ to $6 \mathrm{~h}$ after organic dust exposure was referred to as a 'flu-like illness'. The second part of the questionnaire contained items on details of sheep farming (see Appendix). Some of these items were taken from a previous study (14) on farming in other countries.

Likewise, questions on age, sex, smoking habits (current and past) and the history of the participants' present job were included in this questionnaire. Exclusion criteria included subjects who moved out of the area and subjects who were no longer keeping sheep or were keeping fewer than 10 sheep (for sheep breeders).

In total, 173 farmers comprising 127 sheep breeders and 46 agricultural farmers were interviewed face-to-face by a family doctor on the research team. Subjects were defined as 'sheep breeders' if they kept at least 10 sheep. Among the sheep breeders, only 50 were full-time farmers who worked outdoors among sheep each day. This group was defined as full-time sheep breeders because they had the highest frequency of animal contact. The remainder of the study population worked less than $8 \mathrm{~h}$ a day inside sheep barns and, thus, were defined as part-time sheep breeders. Agricultural farmers were defined as farmers who did not keep sheep within the year preceding the interview. Because of the low number of volunteers, all farmers in these areas were included in the present study.

The Ethical Committee of the Mashhad University of Medical Sciences (Mashhad, Iran) approved the study.

\section{Analysis}

The design of the study was a cohort survey. Differences in the prevalence of work-related symptoms and syndromes between
TABLE 1

Descriptive data of study population

\begin{tabular}{lcc}
\hline & $\begin{array}{c}\text { Agricultural farmers, } \\
\mathbf{n ~ ( \% )}\end{array}$ & $\begin{array}{c}\text { Sheep breeders, } \\
\mathbf{n}(\%)\end{array}$ \\
\hline Target population & 46 & 127 \\
Male & $19(41.3)$ & $79(62.2)$ \\
Female & $27(58.7)$ & $48(37.8)$ \\
Current smoker & $5(10.0)$ & $12(9.4)$ \\
\hline
\end{tabular}

sheep breeders and agricultural farmers were tested by $\chi^{2}$ analysis on two-by-two contingency tables. The 95\% CI of the RR was also calculated. A two-sided P value of 0.05 was the criterion for statistical significance. Risk factors for work-related symptoms were evaluated among sheep breeders using multiple logistic regressions adjusted for age, sex and smoking habit. All analyses were performed with SPSS software (version 11.5, SPSS Inc, USA).

\section{RESULTS}

\section{Subjects}

The mean \pm SD age of the farmers was $34.9 \pm 16.3$ years and $10 \%$ were current smokers (Table 1). Only 50 sheep breeders considered farming as their full-time job.

\section{Prevalence of work-related symptoms}

Ten of 46 agricultural farmers suffered from WRS (Table 2). Sheep farmers had a high prevalence of WRS (48\%) and nasal irritation (37.8\%). Forty-eight of 127 sheep breeders $(37.8 \%)$ reported the presence of a flu-like illness compared with none of the agricultural farmers.

Sheep breeders had a significantly higher risk of overall WRS $(\mathrm{OR}=2.8$ [95\% CI 1.2 to 6.3$])$, nasal irritation $(\mathrm{OR}=4.5$ [95\% CI 1.5 to 12.2$])$, eye irritation $(\mathrm{OR}=3.4$ [95\% CI 1.1 to 10.2]) and breathlessness ( $\mathrm{OR}=3.5$ [95\% CI 1.2 to 10.0$])$ than agricultural farmers (Table 2).

\section{Farming characteristics and work-related symptoms in sheep breeders}

Associations between farming characteristics and work-related symptoms (adjusted for age, sex and smoking habit) are shown in Table 3. In this analysis, working full-time as a sheep breeder, keeping a large number of sheep and sheep shearing were the major risk factors for WRS, asthma and flulike illness. The use of pesticide was a significant predictor for WRS $(\mathrm{OR}=2.3$ [95\% CI 1.0 to 5.3]). The incidence of asthma was almost 12.6-fold higher among sheep breeders keeping more than 500 sheep than among those who kept fewer than 50 sheep. A higher number of working years as a sheep breeder was only a risk factor for flu-like illness $(\mathrm{OR}=1.1$ [95\% CI 1.01 to 1.14$])$.

\section{Distribution of WRS and farming characteristics in sheep farmers}

Table 4 shows the distribution of WRS according to farming characteristics after adjusting for age, sex and smoking habit. The risk of developing work-related wheezing increased significantly with full-time farming (OR=7.1 [95\% CI 2.1 to 23.4]), sheep shearing $(\mathrm{OR}=14.6$ [95\% CI 4.7 to 41.7]) and keeping more than 50 sheep $(\mathrm{OR}=9.5$ [95\% CI 2.7 to 33.5]). A similar relationship was found for breathlessness. 
TABLE 2

Prevalence of work-related respiratory symptoms among sheep breeders and agricultural farmers (control group)

\begin{tabular}{|c|c|c|c|c|}
\hline & \multicolumn{2}{|c|}{ Prevalence (\%) } & \multirow[b]{2}{*}{$\mathbf{P}^{*}$} & \multirow[b]{2}{*}{ OR (95\% Cl) } \\
\hline & Sheep breeders & Agricultural farmers & & \\
\hline Work-related respiratory symptoms & 48.0 & 21.7 & 0.02 & $2.8(1.2-6.3)$ \\
\hline Phlegm & 11.8 & 4.3 & NS & $2.2(0.5-10.5)$ \\
\hline Breathlessness & 31.5 & 10.9 & 0.02 & $3.5(1.2-9.98)$ \\
\hline Wheezing & 16.5 & 4.3 & NS & $2.6(0.6-12.2)$ \\
\hline Flu-like illness & 37.8 & 0.0 & 0.003 & - \\
\hline Nasal irritation & 37.8 & 10.9 & 0.003 & $4.5(1.5-12.2)$ \\
\hline Eye irritation & 24.2 & 8.7 & 0.03 & $3.4(1.1-10.2)$ \\
\hline
\end{tabular}

*Using multivariate logistic regression adjusted for age, sex and smoking habit; $P>0.05$ was considered nonsignificant (NS)

TABLE 3

Prevalence odds ratio (POR) of work-related symptoms and farming characteristics in sheep breeders ( $n=127)$

\begin{tabular}{|c|c|c|c|c|c|}
\hline & \multirow[b]{2}{*}{ Prevalence (\%) } & \multicolumn{4}{|c|}{ POR $(95 \% \mathrm{Cl})^{*}$} \\
\hline & & WRS & Asthma & Nasal irritation & Flu-like illness \\
\hline \multicolumn{6}{|l|}{ Job status } \\
\hline Part-time & 60.6 & $2.9(1.04-8.02)$ & $5.3(1.4-18.1)$ & $1.01(0.4-2.6)$ & $4.9(2.8-10.7)$ \\
\hline \multicolumn{6}{|c|}{ Sheep and other animals } \\
\hline Yes & 26.0 & & & & \\
\hline Yes & 60.6 & & & & \\
\hline No & 39.4 & $2.3(1.01-5.3)$ & $1.1(0.4-3.4)$ & $1.3(0.6-2.8)$ & $1.6(0.7-3.8)$ \\
\hline \multicolumn{6}{|c|}{ Sheep shearing } \\
\hline Yes & 24.4 & & & & \\
\hline No & 75.6 & $5.7(1.8-17.8)$ & $7.9(2.4-26.9)$ & $1.1(0.54-2.6)$ & $4.3(1.6-11.3)$ \\
\hline
\end{tabular}

*Using multivariate logistic regression adjusted for age, sex and smoking habit. WRS Work-related respiratory symptoms (breathlessness, cough, phlegm and wheezing while at work)

Sheep shearing and keeping a large number of sheep were shown to be associated with nearly a fourfold increase in the risk of incidence of phlegm $(\mathrm{OR}=4.4$ [95\% CI 1.5 to 13.5], $\mathrm{OR}=4.3$ [95\% CI 1.1 to 16.3 ], respectively). A similar association was found for incidence of cough.

The present analysis could not confirm a positive relationship between keeping animals other than sheep and WRS.

\section{DISCUSSION}

Animal production has been associated with WRS among farmers $(1,3,9,15,16)$; working in direct contact with animals in animal confinement areas results in exposure to a wide array of hazardous airborne agents (1). Farmers are exposed to a vast array of potential respiratory hazards despite generally being healthier than the rest of the population and having a tendency to smoke less (2). The selection of an appropriate comparison population is a common concern for researchers studying work-related symptoms among farmers. Most studies on animal farming have used nonfarming rural or workingclass populations as their referents and few studies of respiratory symptoms in farmers have been able to make comparisons across agricultural practices to explore the impact of animal exposures $(1,17)$.

In the present study, the prevalence of work-related symptoms and potential risk factors were assessed among Iranian farmers within the year preceding the interview. The European Community Respiratory Health Survey (18) contains items validated for the assessment of respiratory symptoms and disease status. Likewise, farming practices remain stable for some time, so questionnaires assessing farming methods are good proxies for exposure (16).

Comparing farmers raising sheep in the year before the survey with those who did not, we observed a higher prevalence of work-related symptoms among those involved with animal handling. The prevalence of respiratory symptoms, especially breathlessness $(\mathrm{OR}=3.5$ [95\% CI 1.2 to 9.98]), was significantly higher among sheep farmers. Considering that our selected list of farmers live in rural areas and follow traditional methods of agriculture, our results cannot be generalized to all farmers. 
TABLE 4

Distribution of work-related respiratory symptoms and farming characteristics in sheep breeders $(n=127)$

\begin{tabular}{|c|c|c|c|c|}
\hline & \multicolumn{4}{|c|}{ Prevalence OR $(95 \% \mathrm{Cl})^{*}$} \\
\hline & Breathlessness & Wheezing & Cough & Phlegm \\
\hline Full-time versus part-time & $8.7(3.1-24.7)$ & $7.1(2.1-23.4)$ & $1.2(0.5-3.3)$ & $2.3(0.6-9.1)$ \\
\hline Use of pesticide & $1.4(0.6-3.4)$ & $1.1(0.4-3.7)$ & $1.01(0.4-1.8)$ & - \\
\hline Sheep shearing & $5.4(1.9-14.98)$ & $14.6(4.7-41.7)$ & $3.1(1.3-7.4)$ & $4.4(1.5-13.5)$ \\
\hline \multicolumn{5}{|l|}{ Number of sheep } \\
\hline
\end{tabular}

*Multivariate logistic regression adjusted for age, sex and smoking habit

In the present study, an increased frequency of animal contact was associated with an increased risk of work-related symptoms. A significant relationship was shown between the number of daily hours working indoors with animals and the development of work-related symptoms. Our study included 50 sheep breeders who stay outside with their animals almost all day. In this group, the incidence of asthma and flu-like illness was almost fivefold more common than in other sheep breeders, and respiratory symptoms were threefold more common. Our study showed an association between full-time farming and a greater risk of wheezing, which is in agreement with the findings of a European animal farming study (OR=7.1 [95\% CI 2.1 to 23.4 ] versus $\mathrm{OR}=1.57$ [95\% CI 0.77 to 3.2], respectively) (14). Full-time farming was not shown to be a risk factor for breathlessness in the European study (14), as it was in our study $(\mathrm{OR}=0.44$ [95\% CI 0.16 to 1.25$]$ versus $\mathrm{OR}=8.7$ [95\% CI 3.1 to 24.7], respectively).

An increase in the number of animals raised was associated with a higher risk of work-related symptoms. A positive doseresponse pattern of flu-like illness and work-related incidence of phlegm were observed in our study and in a German farmers' study (13). Our results and others' (1) found an increased risk of wheezing with an increased number of animals on the farm, whereas a study of Ohio grain farmers (19) showed an inverse dose-response trend with the number of animals raised.

It is important to understand whether there are multiple hazardous agents creating a synergistic effect. The increased adverse impact of quality and quantity of exposure on workers is important. Radon and Winter (13) discovered an endotoxin content of 58.2 endotoxin units/mg to 193.9 endotoxin units/mg in sheep wool; thus, endotoxin exposure during sheep shearing could be very high. Our results confirmed a great risk of respiratory symptoms, asthma and flu-like illness associated with sheep shearing.

Kimbell-Dunn et al (3) recently described an association between the use of a formaldehyde dip and breathing problems at work. After adjusting for potential confounding variables, the use of pesticides was associated with an increased risk of WRS (OR=2.3 [95\% CI 1.01 to 5.3]) in our study.

Overall, the incidence of work-related symptoms and WRS found in this population while at work was significantly higher than that found in the studies performed in New Zealand, Spain, Germany and other countries $(3,13,20,21)$. These differences could be due to climate, exposure pattern or the method of agriculture in the different countries.

\section{CONCLUSIONS}

Sheep farmers in general have higher rates of work-related symptoms than agricultural farmers. In view of the severity of respiratory symptoms being influenced by the extent of animal contact, our results probably underestimate the impact of this exposure.

ACKNOWLEDGEMENTS: The authors thank the farmers who volunteered in this study for their participation. We could not have completed this work without the hard work of the employees of the Robat-Sang Health Center. The Deputy of Research of Mashhad University of Medical Sciences supported this study. The authors are grateful for the thoughtful comments of Dr Boskabady on an earlier version of this manuscript. Financial support was provided by the Research Department of Mashhad University of Medical Sciences.

\section{APPENDIX}

Questionnaire - Occupational part

- Have you had one or more of the following complaints during work in the last 12 months?

$\begin{array}{lll}\text { Respiratory } & \text { Nasal irritation } & \text { Eye irritation } \\ \text { Breathlessness } & \text { Sneezing } & \text { Itching } \\ \text { Wheezing } & \text { Itching } & \text { Tearing } \\ \text { Cough } & \text { Runny } & \text { Swelling } \\ \text { Phlegm } & \text { Congestion } & \text { Infection }\end{array}$

- Have you ever had physician-diagnosed asthma?

- An attack of asthma during work in the last 12 months?

- Have you ever had a sudden onset of a flu-like illness $2 h$ to $6 h$ after a dust exposure with two or more of the following symptoms:

Fever, chills, muscle ache, weakness, headache, cough, chest tightness, breathlessness

Sheep farming characteristics part (this part is only for sheep farmers)

- Do you regularly work with sheep? (more than 10 sheep)

- How many sheep do you keep? Number:

- Do you work with other animals?

Poultry Cows Goats Other animals

- Do you work with animals in:

Enclosed building Outdoors

- How many hours do you work per day?

Less than $8 \mathrm{~h} \quad$ More than $8 \mathrm{~h}$ (sheep breeder)

- How many years have you been working at this job? Years:

- Do you use pesticide?

- Do you regularly do sheep shearing yourself?

- Smoking habit

Current smoker Ex-smoker 


\section{REFERENCES}

1. Respiratory health hazards in agriculture. Am J Respir Crit Care Med 1998;158:S1-76.

2. Hoppin JA, Umbach DM, London SJ, Alavanja MC, Sandler DP. Animal production and wheeze in the Agricultural Health Study: Interactions with atopy, asthma, and smoking. Occup Environ Med 2003;60:e3.

3. Kimbell-Dunn MR, Fishwick RD, Bradshaw L, Erkinjuntii-Pekkanen R, Pearce N. Work-related respiratory symptoms in New Zealand farmers. Am J Ind Med 2001;39:292-300.

4. Stellmann SD, Boffetta P, Garfinkel L. Smoking habits of 800,000 American men and women in relation to their occupations. Am J Ind Med 1988;13:43-58.

5. Kogevinas M, Anto JM, Sunyer J, Tobias A, Kromhout H, Burney P. Occupational asthma in Europe and other industrialised areas: A population-based study. European Community Respiratory Health Survey Study Group. Lancet 1999;353:1750-4.

6. Preller L, Heederik D, Boleij JS, Volgezang PF, Tielen MJ. Lung function and chronic respiratory symptoms of pig farmers: Focus on exposure to endotoxins and ammonia and use of disinfectants. Occup Environ Med 1995;52:654-60.

7. Terho EO, Husman K, Vohlonen I. Prevalence and incidence of chronic bronchitis and farmer's lung with respect to age, sex, atopy, and smoking. Eur J Respir Dis Suppl 1987;152:19-28.

8. Rask-Andersen A. Organic dust toxic syndrome among farmers. Br J Ind Med 1989;46:233-8.

9. Iversen M, Dahl R, Korsgaard J, Hallas T, Jensen EJ. Respiratory symptoms in Danish farmers: An epidemiological study of risk factors. Thorax 1988;43:872-7.

10. Lyness EW, Pinnock DE, Cooper DJ, et al. Microbial ecology of sheep fleece. Proceedings of a workshop on Bacillus thuringiensis. 1994;49:103-12.
11. May JJ, Marvel LH, Pratt DS, Copollo DP. Organic dust toxic syndrome: A follow-up study. Am J Ind Med 1990;17:111-3.

12. Von Essen S, Fryzek J, Nowakowski B, Wampler M. Respiratory symptoms and farming practices in farmers associated with an acute febrile illness after organic dust exposure. Chest 1999;116:1452-58.

13. Radon K, Winter C. Prevalence of respiratory symptoms in sheep breeders. Occup Environ Med 2003;60:770-3.

14. Radon K, Danuser B, Iversen M, et al. Respiratory symptoms in European animal farmers. Eur Respir J 2001;17:747-54.

15. Dalphin JC, Dubiez A, Monnet E, et al. Prevalence of asthma and respiratory symptoms in dairy farmers in the French province of the Doubs. Am J Respir Crit Care Med 1998;158:1493-8.

16. Danuser B, Weber C, Kunzli N, Schindler C, Nowak D. Respiratory symptoms in Swiss farmers: An epidemiological study of risk factors. Am J Ind Med 2001;39:410-8.

17. Choudat D, Goehen M, Korobaeff M, Boulet A, Dewitte A, Martin MH. Respiratory symptoms and bronchial reactivity among pig and dairy farmers. Scand J Work Environ Health 1994;20:48-54.

18. Galobardes B, Sunyer J, Anto JM, Castellsague J, Soriano JB, Tobias A. Effect of the method of administration, mail or telephone, on the validity and reliability of a respiratory health questionnaire. The Spanish Centers of the European Asthma Study. J Clin Epidemiol 1998;51:875-81.

19. Wilkins III, Engelhardt HL, Rublaitus SM, Crawford JM, Fisher JL, Bean TL. Prevalence of chronic respiratory symptoms among Ohio cash grain farmers. Am J Ind Med 1999;35:150-63.

20. Radon K, Garz S, Schottky A, et al. Lung function and work-related exposure in pig farmers with respiratory symptoms. J Occup Environ Med 2000;42:814-20.

21. Magarolas R, Monso E, Aguilar X, et al. [Prevalence and risk factors of respiratory symptoms in farmers; comment.] Med Clin (Barc) 2000;114:685-9. 


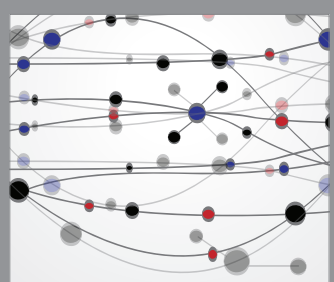

The Scientific World Journal
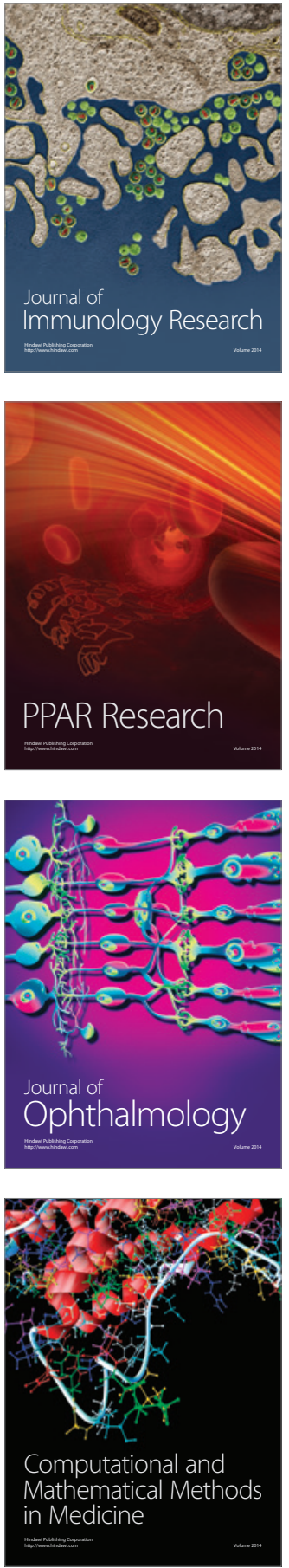

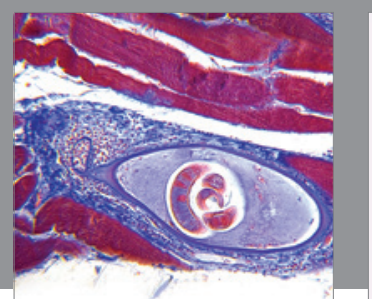

Gastroenterology Research and Practice

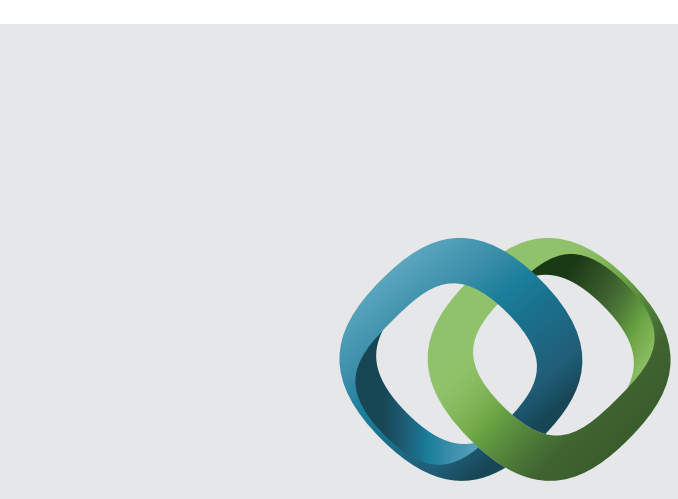

\section{Hindawi}

Submit your manuscripts at

http://www.hindawi.com
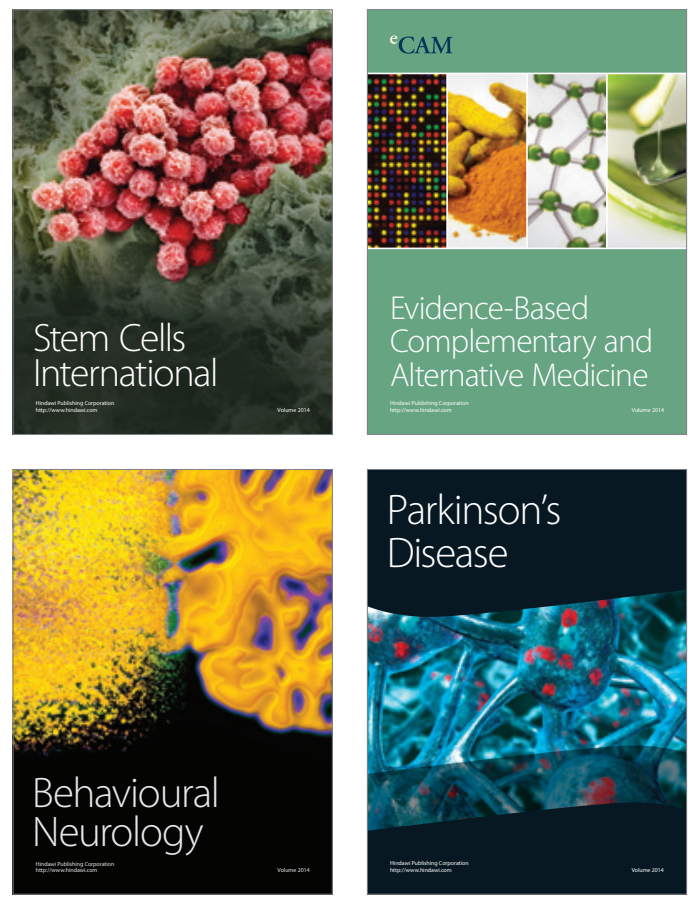
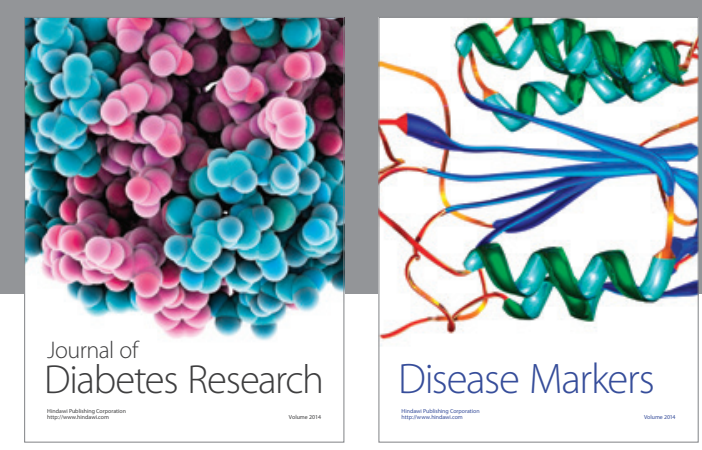

Disease Markers
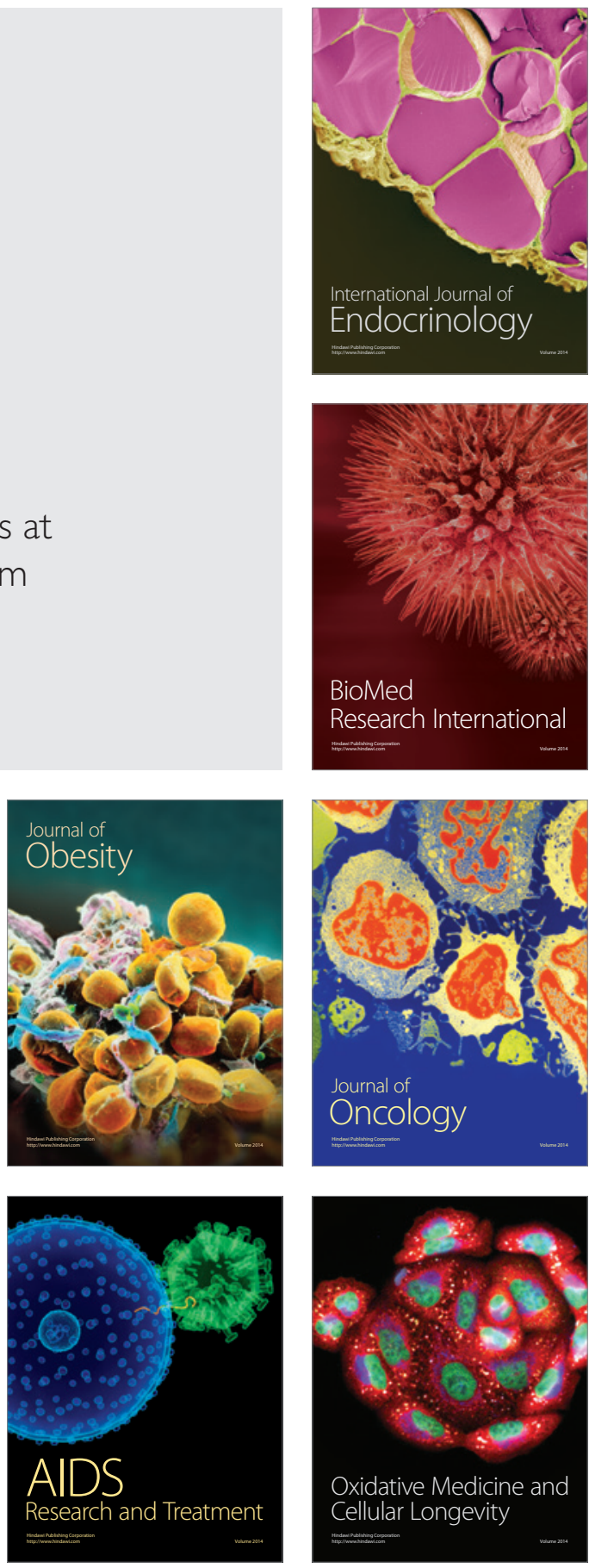